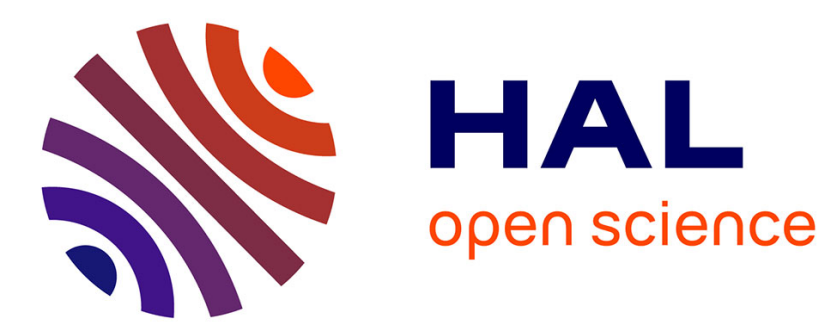

\title{
Venturing into Uncharted Financial Waters: an Essay on Climate-Friendly Finance
}

Jean Charles Hourcade, Baptiste Perrissin-Fabert, Julie Rozenberg

\section{To cite this version:}

Jean Charles Hourcade, Baptiste Perrissin-Fabert, Julie Rozenberg. Venturing into Uncharted Financial Waters: an Essay on Climate-Friendly Finance. 2011. hal-00866434

\section{HAL Id: hal-00866434 \\ https://hal.science/hal-00866434}

Preprint submitted on 30 Sep 2013

HAL is a multi-disciplinary open access archive for the deposit and dissemination of scientific research documents, whether they are published or not. The documents may come from teaching and research institutions in France or abroad, or from public or private research centers.
L'archive ouverte pluridisciplinaire HAL, est destinée au dépôt et à la diffusion de documents scientifiques de niveau recherche, publiés ou non, émanant des établissements d'enseignement et de recherche français ou étrangers, des laboratoires publics ou privés. 


\section{DOCUMENTS DE TRAVAIL / WORKING PAPERS}

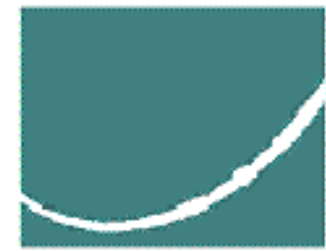

C.I.R.E.D.

No 35-2011

Venturing into Uncharted Financial Waters:

An Essay on Climate-Friendly Finance

Jean-Charles Hourcade

Baptiste Perrissin Fabert

Julie Rozenberg

November 2011

\section{CIRED Working Papers Series}

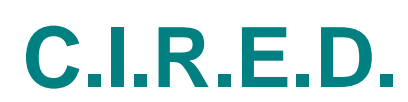

Centre International de Recherches sur l'Environnement et le Développement

UMR 8568 CNRS / EHESS / ENPC / ENGREF

/ CIRAD / METEO FRANCE

45 bis, avenue de la Belle Gabrielle

F-94736 Nogent sur Marne CEDEX

Tel : (33) 143947373 / Fax : (33) 143947370

www.centre-cired.fr 
CIRED Working Papers Series 


\begin{abstract}
This paper explores links between global financial imbalances and tensions around reserve currency along with climate change. Currently, risky levels of private and public debts co-exist with vast amounts of savings which "do not know where to go." Long-term climate-oriented financial products could enhance investors' confidence in low carbon projects (LCP) and channel to them large amounts of private savings. The paper outlines a financial architecture, the cornerstone of which is an agreement on the Social Cost of Carbon (SCC) integrated into a project's appraisal and acting as a surrogate for a carbon price. This SCC would be the value of carbon certificates issued by the government, and delivered to Banks to issue credit facilities reducing the risk-adjusted costs of LCPs. These carbon certificates could be gradually transformed into legal reserve assets of the Banks after verification of the reality of the projects. Finally, the paper considers whether such certificates would be recognized as genuine international reserve assets, backed by the rising value of carbon over time. It shows how emerging countries could then diversify their foreign exchange reserves through an asset based on the international recognition of climate as a global public good.
\end{abstract}

Keywords: Climate Finance, Social Cost of Carbone, carbon certificates, climate agreement, monetary policy.

JEL: E42, E58, G01, G15, Q48, Q54

Essai sur l'architecture financière globale d'une société bas carbone

\title{
Résumé
}

L'accord de Cancun reconnaît qu'en l'absence de prix du carbone, la finance climat est un outil décisif pour aligner les objectifs de développement sur des objectifs de décarbonation de l'économie. Une part conséquente de l'épargne mondiale devrait être redirigée vers les projets bas carbone (PBCs) pour éviter aux pays émergents de s'enfermer dans des trajectoires de développement intensives en carbone.

Dans ce papier nous élaborons une architecture financière globale qui faciliterait à la fois la conclusion d'un large accord climatique entre les pays et une forte augmentation des flux de capitaux dédiés à la finance climat.

Nous examinons d'abord les conditions nécessaires pour que la finance climat déclenche un cercle vertueux de confiance parmi les investisseurs.

Puis nous montrons qu'un accord lors d'une future COP sur la « valeur sociale du carbone » (VSC) et la reconnaissance par les banques centrales d'un actif carbone (qui découle de la VSC) comme nouvelle réserve légale sont deux conditions clés pour produire un effet de levier sur l'investissement dans les PBCs.

Nous tirons enfin les enseignements de la crise financière et expliquons pourquoi les mécanismes proposés ne pourront déployer leur pleine capacité que si le FMI est autorisé à reconnaître les actifs carbone comme de nouveaux actifs de réserve internationaux en contrepartie des PBCs réalisés par ses pays membres. En outre, cet instrument monétaire pourrait contribuer à apaiser les inquiétudes actuelles sur le futur immédiat de la croissance économique et celui de la stabilité des systèmes financiers et monétaires mondiaux.

Mots-clés: finance climat, valeur sociale du carbone, certificats carbone, négociations climat, politique monétaire. 
CIRED Working Papers Series 


\title{
Venturing into Uncharted Financial Waters:
}

\author{
An Essay* on Climate-Friendly Finance \\ Jean-Charles Hourcade ${ }^{1}$, Baptiste Perrissin Fabert ${ }^{2}$ Julie Rozenberg $^{3}$
}

\author{
CIRED
}

November 2011

\begin{abstract}
This paper explores links between global financial imbalances and tensions around reserve currency along with climate change. Currently, risky levels of private and public debts co-exist with vast amounts of savings which "do not know where to go." Long-term climate-oriented financial products could enhance investors' confidence in low carbon projects (LCP) and channel to them large amounts of private savings. The paper outlines a financial architecture, the cornerstone of which is an agreement on the Social Cost of Carbon (SCC) integrated into a project's appraisal and acting as a surrogate for a carbon price. This SCC would be the value of carbon certificates issued by the government, and delivered to Banks to issue credit facilities reducing the risk-adjusted costs of LCPs. These carbon certificates could be gradually transformed into legal reserve assets of the Banks after verification of the reality of the projects. Finally, the paper considers whether such certificates would be recognized as genuine international reserve assets, backed by the rising value of carbon over time. It shows how emerging countries could then diversify their foreign exchange reserves through an asset based on the international recognition of climate as a global public good.
\end{abstract}

Keywords: climate finance, social cost of carbon, carbon certificates, climate agreement, monetary policy

*The current version of this paper received very useful comments from Michel Aglietta (CEPII), John Ashton (UKE3G), Paolo Avner (CIRED), Richard Baron, (IEA), Christopher Beauman (EBRD), François Bourguignon (PSE), Dominique Bureau (CEDD/MEDDTL), Denny Ellerman (MIT), Marianne Fay (World Bank), Gaël Giraud (PSE), Olivier Godard (Polytechnique), Michael Grubb (Cambridge University), Eric Haites (Margaree Consultants), Stéphane Hallegatte (CIRED/World Bank), Claude Henry (Sciences Po Paris/ Columbia University), Stephen King (HSBC), Dimitri Zenghelis (LSE), Ivan Zelenko (World Bank).

\footnotetext{
${ }^{1}$ Head of CIRED (International Centre of Research in Environment and Development)

e-mail : hourcade@ centre-cired.fr

2 Phd candidate at CIRED, perrissin@centre-cired.fr , corresponding author

${ }^{3}$ Phd candidate at CIRED, rozenberg@centre-cired.fr
} 


\section{Introduction}

After the failure of COP-15 in Copenhagen (2009) to find a successor to the Kyoto Protocol, the Cancun Agreement (COP-16) calls for "a paradigm shift towards building a low-carbon society that offers substantial opportunities and ensures continued high growth and sustainable development" (paragraph 10). It confirms the failure of finding an agreement within a burden-sharing paradigm (Hourcade et al., 2008) which boils down to asking the question: "who uses the remainder of the emissions budget?" For developing countries this paradigm contradicts the sustainable development perspective of the UNFCCC (Rio 1992) since it requires their emerging middle classes to slow their access to decent living conditions and relegate the world priority of alleviating poverty to a later era.

As a keystone of an alternative approach, the Cancun Agreement establishes a Green Climate Fund devoted in part to funding low-carbon development projects (LCPs), their adaptation and capacity buildup. This fund is a precondition, long called for by developing countries ${ }^{4}$, for setting up, one or more market-based mechanisms to enhance the cost-effectiveness of, and to promote, mitigation actions" (paragraph 80).

Given the reluctance of countries like the US, Canada and Russia to adopt binding emission targets, creating a demand for emissions credits by developed countries remains unattainable in the near future. This paper tackles the contradiction between this absence of worldwide carbon markets ${ }^{5}$ and the necessary scaling up of climate finance within a context where governments of developed countries face fiscal constraints and banks are obliged to make deleveraging efforts.

It starts from the observation that, given the orders of magnitude at stake, climate finance can no longer remain marginal, and that private investments in development projects, whatever their content, are primarily constrained by the perception of high uncertainty about returns. It suggests that financial devices preferentially reducing the investment risks of LCPs could unleash margins of freedom which would give them a boost even in the transitory absence of carbon prices and that the design and deployment of these devices cannot be made without taking into account the evolution of the overall financial system.

Linking these two sensitive issues may appear to be a diplomatic non-starter. But ignoring that "social and economic development and poverty eradication are the first and overriding priorities of developing countries and that a low-carbon development strategy is indispensable to sustainable development" (paragraph 6) is also a diplomatic non-starter. After all, if reorienting part of the world's savings towards low carbon energy, transportation and the housing infrastructure can trigger a wave of sustainable growth (UNEP, 2009) which is less exposed to financial ups and downs, this link is worth examining.

We first specify the nature of the difficulties climate finance must confront: defining the appropriate form of the multilateral Green Climate Fund, hedging the serious risks of distrust if raised expectations are not fulfilled. We then show that an agreement at a future COP on the value of the Social Cost of Carbon (SCC) can help overcome these risks and improve the overall economic efficiency of

\footnotetext{
4 See Earth Negotiations Bulletin published by the International Institute for Sustainable Development (IISD) Vol. 12 No. 156 (http://www.iisd.ca/vol12/enb12156e.html)

${ }^{5}$ The carbon markets like the EU-ETS and possible markets in a few states in the USA (California) will not generate a demand of carbon offsets through the Clean Development Mechanism large enough to provide the necessary investments and target them towards highly capital intensive infrastructure.
} 
multilateral and voluntary initiatives of Parties to leverage investments for low carbon infrastructures. We then examine how, in the aftermath of the financial crisis, recognition by the IMF of a carbonbased international reserve asset as a counterpart to countries' investments in LCPs can make it possible to secure future economic recovery and the stability of the monetary and financial system.

We do not claim to depict a full-fledged proposal; we simply mean to embark the reader upon reflections aimed at breaking the circle of distrust that has so far frustrated attempts to find a successor to the Kyoto Protocol.

\section{After Cancun: Making the Paradigm Shift Happen}

\subsection{The reasons for an impossible agreement upon a world carbon price}

A cap-and-trade architecture for climate policies is justified by the theoretical merits of a unique carbon price around the world. But after years of repeated failures in enforcing this principle it may be wise, instead of blaming political and diplomatic vagaries, to recall the alerts against too hasty a policy interpretation of economic wisdom (Aldy et. al., 2003, Aldy and Stavins, 2007). ${ }^{6}$

Economists indeed know that valid recipes in a first best world (i.e. with competitive frictionless markets and lump-sum transfers to compensate adverse redistributive impacts) may not lead to Pareto improving outcomes if applied to a real (second best) world (Lipsey and Lancaster, 1956) ${ }^{7}$. The last IPCC report for example places a caveat ${ }^{8}$ on the optimistic results of the modeling literature which suggests that, with a unique carbon price, even the tightest climate targets can be met with only a limited percentage of GDP losses over the century. The RECIPE project (2009) confirms that, in case of imperfect expectations, technical inertia and imperfect markets, a carbon-price-only framework hardly offers a palatable deal for emerging and developing countries. Indeed, in a transitory phase any significant rise in carbon price would severely hurt their low and middle classes as well as their basic industries at the moment of economic take-off (Hourcade and Guivarch, 2010). The problem is that one cannot but be skeptical about the willingness of OECD countries to grant large compensatory transfers (by means of aid or generous emissions caps) to offset these adverse impacts.

This problem is often underestimated because of a misinterpretation of modeling results. Many of them assume perfect expectations which means, as illustrated in Figure 1, that economic agents "see" the entire trajectory of carbon prices equal to the SCC along the optimal least-cost pathway to achieve a given climate objective. They thus make decisions today on long-lived investments as a function of, say $200 \$ / \mathrm{tCO}_{2}$ in 2080 , and apply a low $10 \$ / \mathrm{tCO}_{2}$ to the current generation. In the real world, however, economic agents act in a more myopic fashion because long term markets are missing and

\footnotetext{
${ }^{6}$ The Kyoto protocol for example is improperly presented as a unique price framework. It basically consists of quota exchange among countries, which are in turn free to implement unilateral domestic climate policies. Consequently, it implies a world carbon price but not a unique carbon price (Guesnerie, 2010).

${ }^{7}$ If there are some constraints within the GE system that prevent the attainment of at least one of the conditions of Pareto optimality, then the attainment of the other Pareto optimal conditions is no longer necessarily welfare improving (Lipsey and Lancaster, 1956)

8 "Most models use a global least cost approach to mitigation portfolios and with universal emissions trading, assuming transparent markets, no transaction cost, and thus perfect implementation of mitigation measures throughout the 21 st century" (AR4 WGIII SPM Box 3). On differences between $1^{\text {st }}$ best and $2^{\text {nd }}$ best economics in the field see Stern (2010)
} 
because carbon price signals in sectors as critical as transportation and building infrastructure are swamped by many other distorted economic and political signals 9 .

This causes an expectation gap that is all the more harmful because developing countries are going to build a significant amount of infrastructure within the next two decades and will soon be locked into carbon intensive developmental patterns. There is thus a narrow window of opportunity for avoiding this bifurcation by shifting the content of investments in energy, building, transport and end-use equipment (Shalizi and Lecocq, 2009).

This shift is primarily a matter of bridging the expectation gap. Doing so only by means of the carbon price signal implies very high carbon prices in the short term to cover the noise of other signals (see figure 1). This will exacerbate transition costs. There is therefore a need to mobilize a broader set of economic signals (energy pricing, real estate and land prices, labor markets and risk premium) together with institutional reform of infrastructure sectors. Governments will have to enact such policies for a far larger set of domestic reasons than climate change (Shukla, 2011).

Figure 1: The expectation gap. Agents today consider the carbon price $a$, and do not anticipate its evolution beyond $t_{1}$. In case of full confidence in public policies and clear perception of carbon price signals they see the entire trajectory $O$. If carbon prices are blurred by other imperfect signals (including low confidence in public policies), a carbon price $c>b$ has to be launched. It leads to the $L$ curve in the case of endogenous technical change.

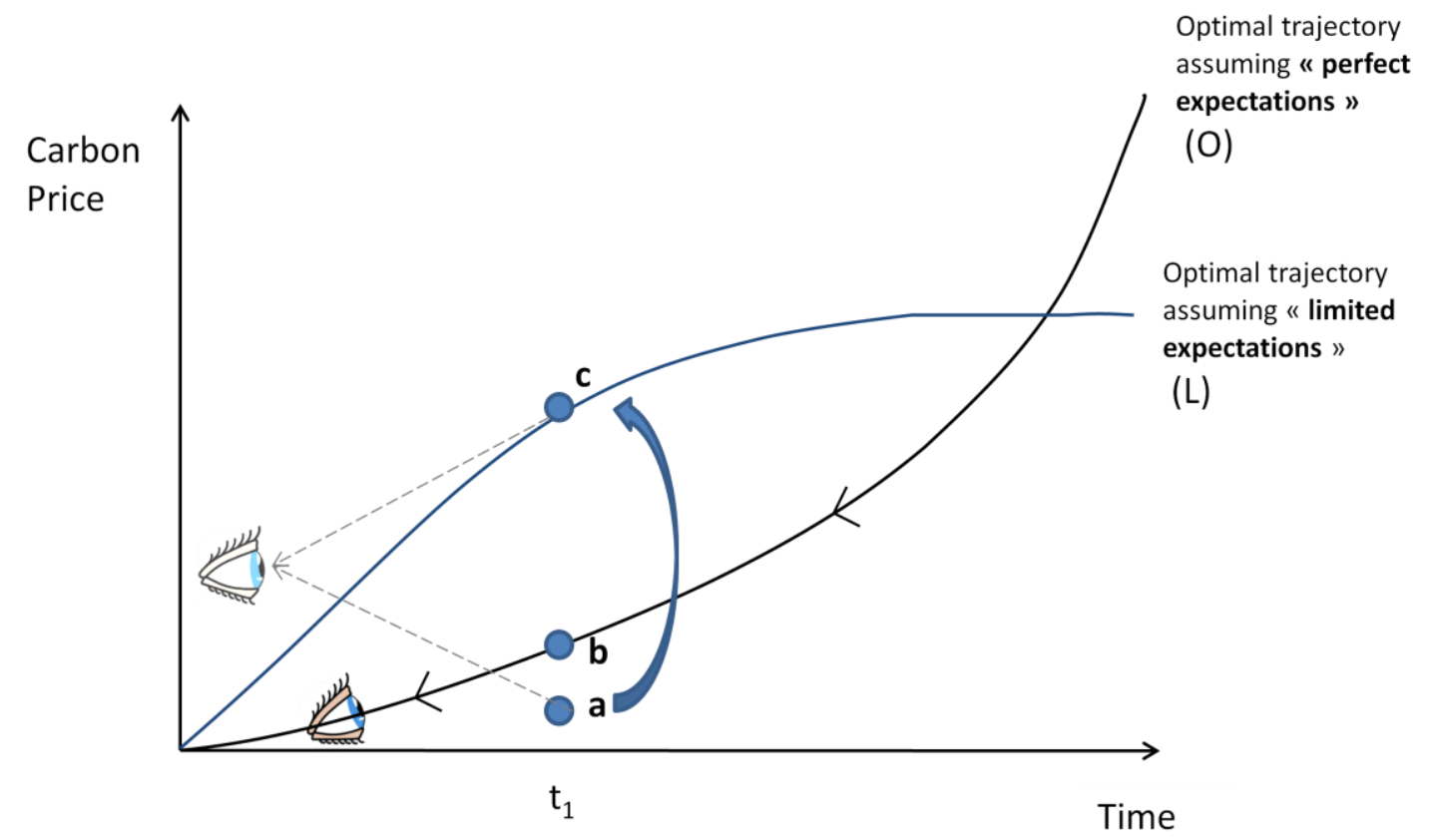

We thus examine how an international agreement on the Social Cost of Carbon (SCC) could help bridge (part of) this expectation gap and reorient infrastructure investments today without the immediate adverse effects of high carbon prices on income distribution and industry.

\footnotetext{
${ }^{9}$ In addition, there are many views about the potential for reducing market and institutional imperfections. Each view leads to a specific trend of SCC and the uncertainty about which view will politically prevail is one major source of "myopic" decisions.
} 


\subsection{Climate finance, under a form of double-bind?}

The Cancun Green Climate Fund and other forms of climate finance are necessary tools to bridge this expectation gap (Müller, 2011). But they may be victims of misunderstandings if they are not inserted into a broader view of developmental issues ${ }^{10}$ and if a credible response is not given to "donor fatigue." This fatigue cannot but be exacerbated in a context of "depression economics" and access of large emerging countries to the rank of capital exporters.

It is unlikely that the US\$ 100 billion per year by 2020 appraised by (Smith et al, 2011) and (Olbrisch et al. 2011) or the US $\$ 140-\$ 175$ billion a year by 2030 appraised by the World Development Report (and corresponding to US\$264-\$563 billion upfront financing needs (World Bank, 2009) for both mitigation and adaptation can be covered by grants from developed countries given their current financial fragility. Current ODA is only $\$ 100$ billion per year today and, if public grants can certainly cover adaptation costs, mobilizing private finance is needed for large scale mitigation investments.

The above figures show that climate finance cannot be considered as a marginal issue. We must stress however that the incremental investment costs to be covered do not confront major macro-economic constraints. The World Energy Outlook 2009 by the IEA evaluates the incremental investment costs for a 450ppm GHG concentration scenario as amounting to only 3\% of total GFCF (Gross Fixed Capital Formation) assuming a world growth rate of 3\% over the period (own calculations). This is because the higher upfront costs of low carbon technologies are in part compensated for by a lower energy demand due to higher energy efficiency and changes in consumption behaviors. The same compensation operates between lower demand and higher capital intensity in the transport sector.

We are thus not facing a problem of global capital shortage or sacrifice of current consumption ${ }^{11}$. Considerable amounts of capital are indeed available in developed countries' pension funds, in revenues derived from all kinds of rents (oil, gas, real estate and land), and in the very high savings rates of large emerging economies. It is, indeed, primarily a capital redirection problem and new margins of freedom for a palatable deal between Annex 1 and non-Annex 1 countries would appear if it were possible to enhance investors' confidence in alternative content of the bulk of infrastructure projects.

CDM experiences (taking place in about 30 Annex I and 80 host countries) teach us major lessons in this respect. First the magnitude of generated cash-flows depends on the demand of carbon offset by countries subject to emissions commitments which is precisely today's main cause of uncertainty. In the aftermath of the financial crisis and of the Copenhagen failure, CDM contracted by 59\% in 2009 (Kossoy and Ambrosi, 2010) ${ }^{12}$. Second, revenues from carbon trading can be used to support all kinds of projects, even those which are carbon intensive ${ }^{13}$. Third, cash-flows which enhance the profitability of LCPs cannot overcome the financial barriers of upfront investments because they are generated

\footnotetext{
${ }^{10}$ of which President Lula's response to a goodwill European offer at Copenhagen is symptomatic: "in these circumstances we do not want your money"

${ }^{11}$ About the possibility to avoid a trade-off between present consumption and future climate see Foley (2008)

${ }^{12}$ In addition, two other sources of uncertainty limit the volume of available transfers: a) the possible existence of ceilings on carbon imports, consistent with the "supplementary condition" of article 17.bis of the Kyoto Protocol, b) the inexistence of a sharing of the proceeds levied on primary and secondary carbon trading.

${ }^{13}$ We set aside here the criticisms on the use of a counterfactual emissions baseline which casts doubts on the effectiveness of emissions reductions.
} 
only when emission reductions are observed, which is well after the funding of the project (De Gouvello and Zelenko 2010).

Contrary to the CDM, the Public Finance Mechanisms (PFMs) developed by several financial organizations ${ }^{14}$ and bilateral funds bring upfront and technical assistance grants to LCPs from their incubation to their operational phase. However, as the Kyoto mechanisms, they bet on LCPs eventually being rewarded, in addition to non-monetary local co-benefits, by the revenues from significant carbon prices. Moreover they provide grants which do not finance the bulk of projects (Neuhoff et al., 2009) and cover only the 'extra risk' of LCPs, assuming that the bulk is already funded and has met a certain risk-adjusted return criterion.

This may explain why the current magnitude of PFMs pales in comparison with the funding needs (UNEP, 2010) and why their leverage ratio on private investment, assessed by the High-level Advisory Group on Climate Change Financing (AGF, 2010), is lower than the usually observed ones from traditional PFMs: between 2 and 4 for LCPs for every US $\$ 1$ of public money ${ }^{15}$ compared with US\$3 to US\$15 (J. Maclean et al., 2008, J. Ward et al., 2009).

Currently the scaling up of climate finance is trapped in a form of double-bind. On one hand, it is one precondition for breaking the circle of distrust between Annex B and non-Annex B countries and for proving the capacity of the former to assume their past responsibility in global warming. On the other hand, in the absence of a global arrangement, bi-lateral initiatives, or even proposals like taxes on bunkers or flight transports or bilateral initiatives may look like symbolic tricks, leading to fragment assistance and ultimately creating a source of inefficiency and distrust ${ }^{16}$.

\subsection{Back to the fundamentals: risk-adjusted costs of upfront investments}

To break this double-bind, let us start by noting that low carbon development projects are confronted with the usual risks of all development projects: technical and regulatory uncertainty, currency risks, long pay-back periods and volatility of market prices. Their specific drawback is that these risks are enhanced by the uncertainty on carbon prices, by higher upfront costs due to higher capital intensity of low carbon equipment and by higher technological risks of less mature techniques (Grantham Research Institute, 2009).

Total costs of projects are comprised of their upfront costs, operating costs and the costs of the perceived risks. Let us assume (see figure 2) that upfront costs of a LCP are $10 \%$ higher than those of a BAU project and its intrinsic, non carbon-related risk amounts to 20 (respectively 10 for the BAU project). The present value of operating costs of the LCP is lower than the BAU but not low enough to compensate for its excess upfront cost. Let us now assume that the present value of the penalty the BAU project would pay in case of a climate agreement upon a carbon price is 10 . Assuming a $25 \%$

\footnotetext{
${ }^{14}$ GEF (Global Environment Facility), SCCF (Special Climate Change Fund), CIF (Climate Investment Fund), CTF (Clean Technology Fund), CPF (Carbon Partnership Facility)

${ }^{15}$ Such estimates do not take into account the whole array of positive externalities generated by the PFMs, including the support to multiple generations of investments, and markets that continue to grow after the public funds are expended.

${ }^{16}$ The economic costs of fragmentation are underlined on the Paris Declaration on Aid Effectiveness and in the Bali action plan in the case of overseas aid mechanisms. A symptom of distrust around climate finance is the refusal of developing countries to treat climate grants as an aid, the purpose and destination of which would be determined by the donor. Another lies in the failure of ICAO and IMO to act. This failure has prompted the EU to take unilateral action in the hope of provoking an agreement for international action but many emerging economies perceive this initiative as a protectionist measure.
} 
subjective probability for such agreement, the carbon-related risk of the BAU project amounts to 2.5. Then, as the difference in total risk-adjusted costs of the two projects reaches 12.5 points, the LCP must reduce its risk-adjusted costs by $9 \%$ to be competitive.

Figure 2: Making low carbon projects attractive

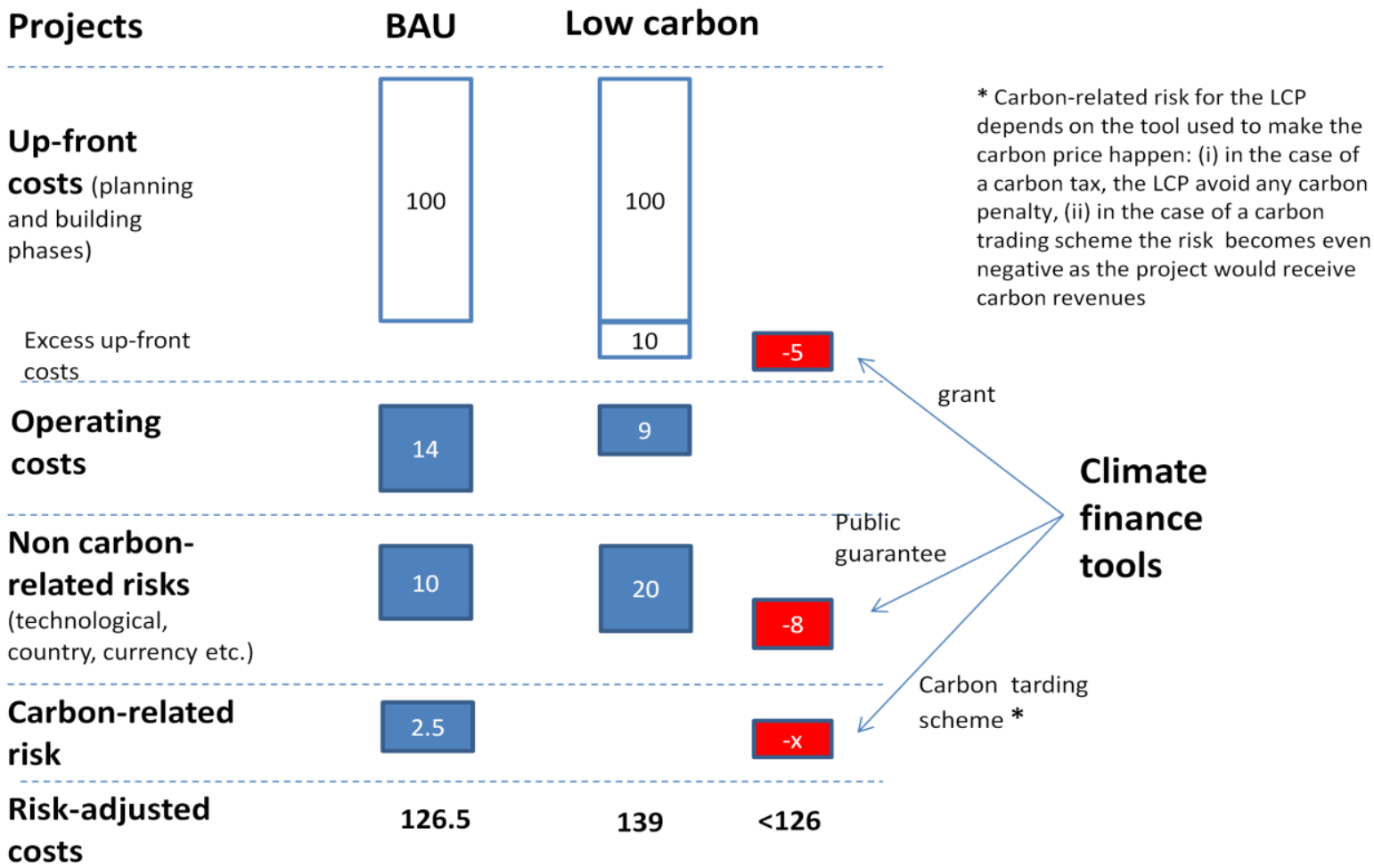

For historical reasons climate finance has thus far focused on covering the incremental upfront costs of $\mathrm{LCPs}^{17}$. There are however other means to lower LCP's total risk-adjusted costs:

Increasing the chances of an agreement upon the implementation of a carbon price: a full certainty case makes the risk-adjusted costs of the BAU projects become 134. If such agreement took the form of a carbon trading system, it would even turn the carbon-related risk into a source of revenue for the LCP, tilting the balance in favor of the LCP as soon as the carbon revenue exceeds 5.

Addressing the non-carbon price risks of the LCP: halving them by means of public guarantees will give the same result as paying the totality of excess upfront costs (10) through public grants for example (our proposal based on carbon certificates presented in section 2 belongs to this category of climate finance mechanisms). In this example additional support $(+2.5)$ is required to help the LCP reach the breakeven point.

Blending the tools and widening the scope of public intervention in order to address the bulk of the financing needs of LCPs and reduce the overall risk-adjusted costs of LCPs.

Hence, public support will be needed to make LCPs competitive, but the challenge is firstly to design innovative instruments aimed at lowering risk perception of LCPs by private investors so as to

\footnotetext{
${ }^{17}$ On top of the difficulties of measuring these 'incremental costs', this notion makes the selection of negative costs projects difficult; the demonstration of transaction costs explaining why projects which should but will not be funded in practice is indeed always a very controversial exercise.
} 
maximize the leverage effect of each $\$$ of public money in a context where carbon prices are unlikely to rise. De Gouvello and Zelenko (2010) for example propose a Low Carbon Development Facility (LCDF) which would fill up a Green Fund emitting \$100 billion AAA green bonds per year to back LCP projects globally rated BBB. This is the right way to go, however, as it stands, this proposal has two drawbacks: it implies a one shot budgetary cost of $\$ 68$ billion (the paid-in-capital of the fund) and can be suspected of crowding out other types of development assistance. Moreover it incorporates no guarantee that the collected money will yield cost effective abatements. In addition to stringent monitoring of the projects, this guarantee cannot be brought without a surrogate of carbon prices.

\subsection{An agreed upon Social Cost of Carbon as a surrogate of a carbon price}

A natural candidate to a surrogate of a carbon price is the Social Cost of Carbon (SCC) and its evolution over time. The SCC is theoretically the set of shadow prices of carbon along a constrained GHG emission trajectory and its value increases over time as one approaches carbon constraints as long as very cheap carbon free techniques are not available at large scale. This is the important point because, incorporated in projects appraisals it would counterbalance the effect of the discount rate and enhance the social value of long-lived infrastructure projects.

The modeling literature displays a wide range of value for the SCC (between US\$0/ $\mathrm{CCO}_{2}$ and US $\$ 240 / \mathrm{tCO}_{2}$ in 2030 in IPCC AR4) because of differences in a) the choice of the decision framework (cost-benefit with a monetary assessment of climate change damage vs. cost-efficiency with a predetermined temperature target) b) assumptions about the level and pace of climate change damage, the costs and pace of deployment of low carbon technologies, the pure time preference and the long term growth rates. Although integrated modeling can help defining a narrower corridor of plausible values of the SCC at various points in time, the choice of this value will be ultimately political in nature ${ }^{18}$ and translate the willingness of governments to act for mitigating climate change.

We believe that an agreement on a SCC is low demanding in terms of diplomatic accord at the UNFCCC. It does not entail the same drawbacks as an agreement leading to a carbon price to be imposed immediately to all world human activities. It will, similarly to what the French tradition calls a prix directeur, be used to bridge the expectation gap by indicating the long term value of the ton of avoided GHGs emission and increase the relative attractiveness of LCPs with no direct immediate burden for private agents. It will also help maximizing the overall economic efficiency of the Green Climate Fund and of any other climate initiatives, while sending a comprehensive signal to investors and, upstream, to R\&D, city planning and infrastructure managers.

What remains to be demonstrated is what device should use this SCC in a credible enough manner to encourage governments, at least a coalition of few willing countries, to create new channels for funding LCPs and increasing their participation to the endowment of the Green Climate Fund.

\footnotetext{
${ }^{18}$ Perrissin-Fabert et al. 2009 show that this corridor is narrower if each Party (i) adopts a stochastic sequential decision framework and (ii) accepts that in a first step the worldviews of the others have a chance to be right. Then, the various Parties may then accept similar SCC for different reasons. This type of configuration was examined for the discussion of price-caps at COP6 (Hourcade et al., 2002).
} 


\section{Turning the Social Cost of Carbon into a Fulcrum for Climate Finance}

The basic principle of the solution proposed here for overcoming the gap between public budget constraints and upfront costs of any ambitious climate policy consists in governments injecting more liquidity into the economy with the help of central banks, provided that the money is used to fund $\mathrm{LCPs}^{19}$, and redirecting private capital toward LCPs. No "hard cash" needs to be disbursed by governments which provide instead a public guarantee on a precise type of credit. We will come back to this point later. The question is how to use this guarantee to differentiate prudential rules of the banking system contingent on the nature of the projects and to attract savings from institutions such as pension funds without generating uncontrolled money creation and "carbon bubbles." This is precisely where the SCC enters the game.

\subsection{The SCC and the mechanics of climate finance scaling-up in an adverse context}

There are two channels to scale up climate finance: encouraging banks to provide loans to LCPs and bringing institutional investors into the low-carbon sector. Let us examine them in turn before sketching a possible overall architecture.

\subsubsection{Bringing the banking system in}

Given current constraints of the banking system, two levers can prompt the banks to become involved in LCPs: new credit facilities through an increase in their legal reserves and innovative means of recapitalizing them in a context of broad deleveraging. If the mitigation of climate change is recognized as something of value by a country, then the government could activate these two levers by creating "carbon certificates" recognized by the central bank as genuine reserves ${ }^{20}$. Instead of being valued at market prices like gold or foreign currencies, the value of these certificates would be set at the conventional value of the SCC. Governments could then deliver them to the banking system, preferably but not exclusively to development banks, in proportion to expected carbon abatement yielded by the projects they support.

As depicted in table 1 and 2, carbon certificates accrue to banks' assets holdings and are turned gradually into new legal reserves (and therefore appear as carbon certificate deposits in central bank liabilities) or carbon equity after due verification that projects have been launched and completed. One possible mechanism of this transformation of carbon certificates into legal reserves in order to preserve the financial and environmental integrity of the system is given in appendix 1.

This transformation is critical to incite banks to add carbon finance to the short list of their priorities. They would perceive carbon finance as a way to gradually increase their legal reserves and would be incited to release, for instance, regular deposits to the central bank in order to develop LCP-targeted credit facilities. The other lever consists in turning carbon certificates into carbon equity. This operation would help the banks (at least cost) to comply with their prudential ratio (Bâle III), or expand their activity depending on their previous situation.

\footnotetext{
${ }^{19}$ Such a precondition is crucial to controlling the induced monetary multiplier and making sure that the money is effectively invested and may eventually unleash macroeconomic benefits in terms of potential growth.

${ }^{20}$ Provided that this operation is conducted consistently with domestic practices about operating rules of the Central Banks
} 
The counterpart of these liabilities on the assets side of the central bank's balance sheet is the "carbon assets" valued at the SCC. Setting aside the question of the international liquidity of these assets, their issuance could be a unilateral decision to transform the avoided carbon emissions into tangible assets because the international community has recognized that it is something of value.

The attribution by the Central Bank of a conventional value to this carbon asset in the same fashion as gold under the Bretton Woods regime for instance, does not infringe on its independence. It is justified by an upstream UN agreement on the SCC and backed on the existence of effective emission reductions. Still this poses a problem of accounting methodology which we address later.

Table 1 The Central Bank balance sheet (simplified)
Assets
Liabilities

$\begin{array}{ll}\text { Gold } & \text { Currency in circulation } \\ \text { SDR } & \text { Deposits of commercial banks }\end{array}$

Securities

Carbon assets Carbon certificates deposits of commercial/development banks

Table 2 Development and commercial banks balance sheet (simplified)
Assets
Liabilities

$\begin{array}{cll}\text { Legal reserves: } & \\ -\quad \begin{array}{l}\text { deposits with Central Bank } \\ \text { carbon certificates } \\ \text { deposits }\end{array} & \begin{array}{l}\text { Capital (private equity, } \\ \text { carbon equity) }\end{array} \\ -\quad \begin{array}{l}\text { Additional Cash (LCP } \\ \text { loans' returns) }\end{array} & \begin{array}{l}\text { Green bonds } \\ \text { (development banks) }\end{array} \\ \text { Loans: } & \\ -\quad \text { regular loans } & \\ - & \text { "LCP loans" } & \text { LCP-targeted financial } \\ & & \text { products } \\ & & \text { (commercial banks) }\end{array}$

Back to the example in figure 2, if we assume that public funds could take on half the upfront excess costs (5), our proposal of CC issuance has to yield an additional reduction of risk-adjusted costs of at least 8 points in order to make the LCP competitive. Then the LCP will be funded if it can be demonstrated that the $\mathrm{CC}$ delivered to the Banks that account for a share of the amount of abated carbon emissions valued at the conventional SCC is worth at least 8 (which is a likely and even 
conservative value given that carbon penalty for the BAU project is expected to be 10). If such is the case, after verification of the completion of the project, these 8 will be dispatched between Bank's legal reserves and carbon equity. If the project does not meet its carbon abatement objectives, then only a fraction of these 8 will be turned into legal reserves or carbon equity. The project would thus have benefited from the loan while the bank would not get extra legal reserves or carbon equity as expected.

\subsubsection{Bringing Institutional Investors in}

Launching the mechanism demands the governments to back, through carbon certificates, the credit risks of LCPs. The crux of the matter, to enhance the power of the system and its financial viability is however to redirect toward LCPs the funds that would otherwise be invested in BAU projects. With carbon certificates backed on the SCC, the banking system holds an operational tool to back safe climate-oriented financial products (bonds ${ }^{21}$ or liquid deposit accounts) with a slightly higher return than the return of other safe products (e.g. gilt-edged securities, savings bank accounts, government bonds, interest bearing accounts).

This may be attractive for households which allocate a share of their savings to safe investments and/or have a non negligible ethical motivation to financially contribute to "great causes."22 Besides, institutions like Sovereign Wealth Funds, public private and corporate pension funds, insurance companies, endowments and investment management companies could be interested in AAA-rated 'climate colored' bonds (such as the green bonds of the World Bank) if they offer a slightly higher return than regular bonds. The moment is timely in the aftermath of the financial crisis since households and some of the institutional investors are becoming more careful about speculative investments.

\subsubsection{Closing the system}

As pictured in Fig. 3, the carbon targeted financial back up by governments and the mobilization of private savings allows banks to provide loans directly to LCPs or to specialized funds meant to operate the selection of LCPs and create lower risk portfolios of projects. With carbon certificates used as financial counterparts of effective LCPs, we can, as in De Gouvello and Zelenko (2010), design least cost devices to enhance the credibility of LCPs portfolios.

\footnotetext{
${ }^{21}$ AGF (2010) sees the green bonds in development banks' capital as a good option for climate finance.

${ }^{22}$ Socially Responsible Investment (SRI) accounts for $10 \%$ of total European asset management; its volume increased by $87 \%$ between 2007 and 2009 according to Eurosif. Moreover, investors may integrate green ratings of asset management funds into their decisions.
} 
Figure 3: Sketching a possible climate finance architecture

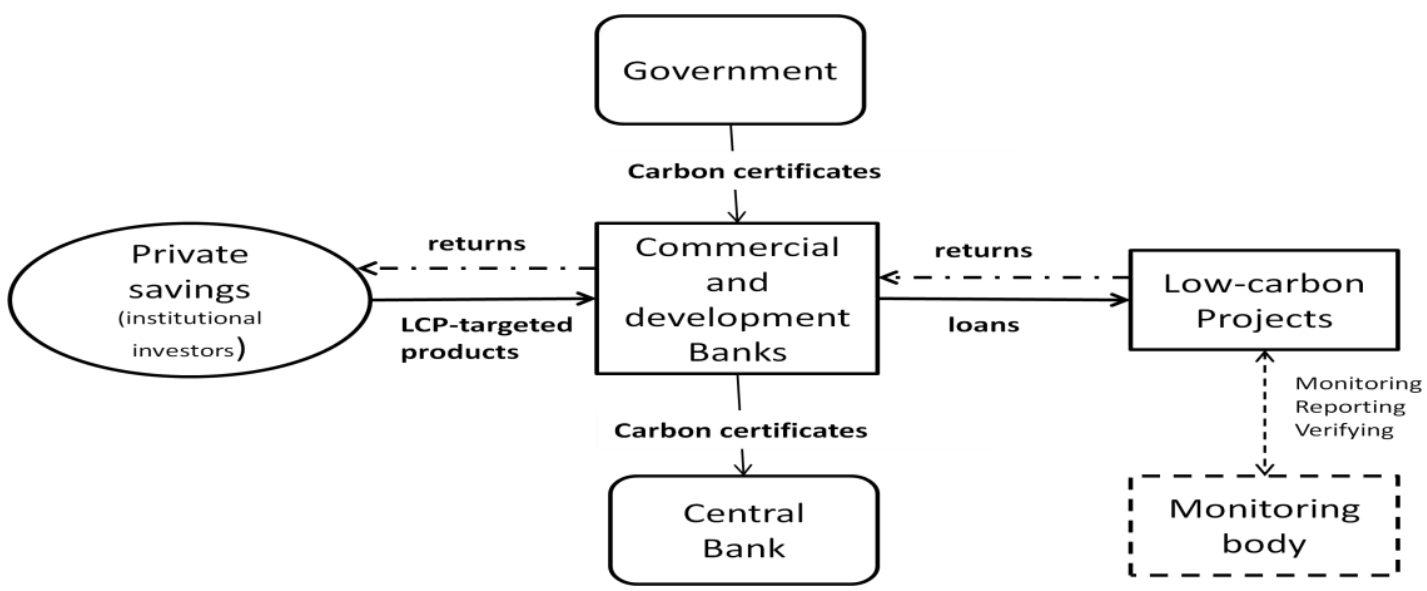

However, this type of sleight-of-hand finance logically arouses suspicion because of its responsibility in today's financial crisis. It may indeed conceal a systemic risk through creating monetary inflation and incentives to invest in new speculative assets. Figure 4 pictures the three legitimate concerns that have to be responded to: (i) lax monetary creation under the pretext of carbon savings, (ii) low quality of LCPs both in terms of development and carbon abatement, (iii) generation of 'carbon bubbles'.

Figure 4: The SCC and the credibility of a climate finance architecture

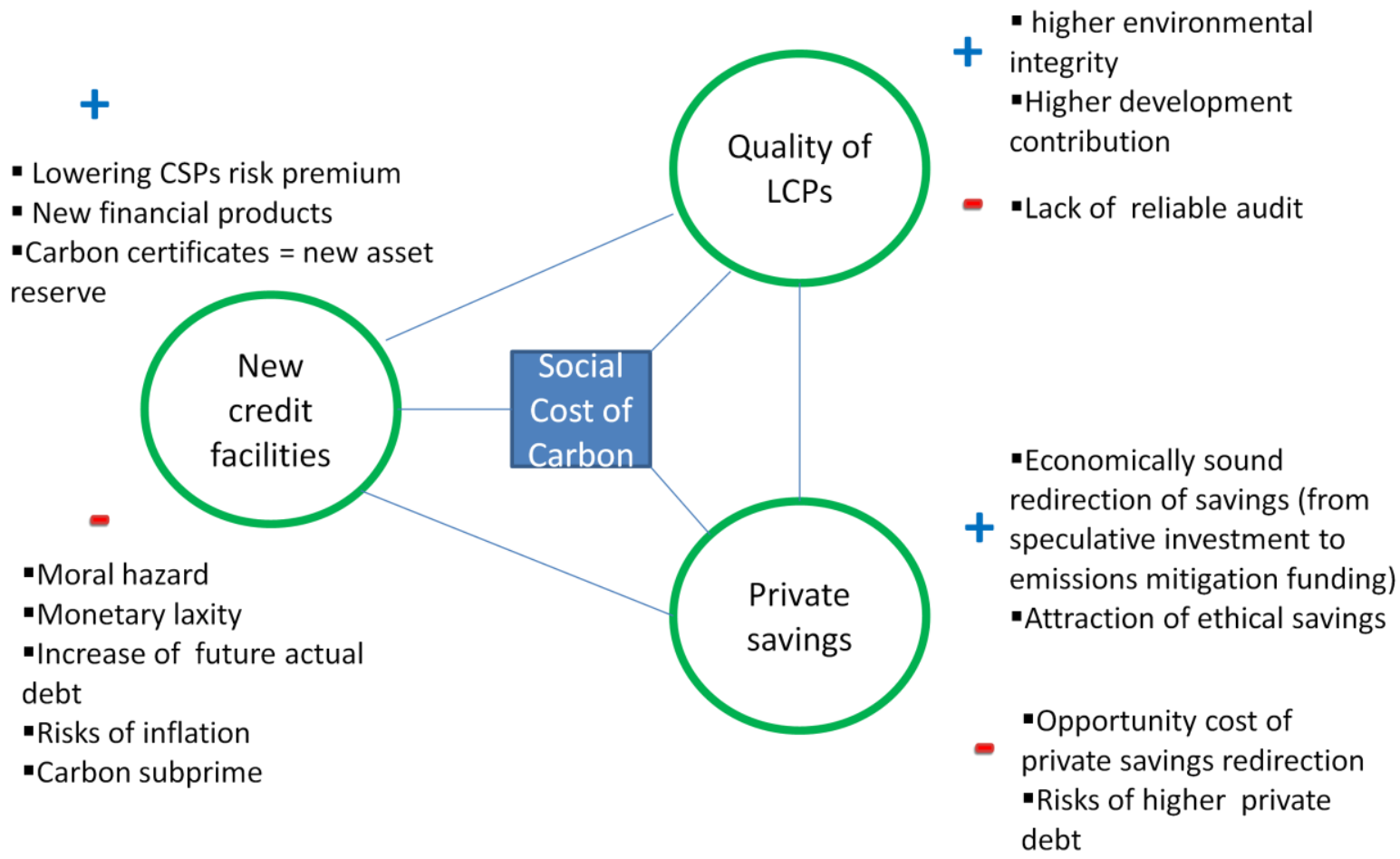

A moral hazard problem arises for both banks and project developers faced with the incentive to fund low environmental quality LCPs, for the former because carbon certificates increase their legal reserves, for the latter because they are interested in overestimating the mitigation contribution of their project. 


\subsection{Securing LCPs environmental and developmental quality}

The reliability of this architecture rests primarily on its capacity to certify that LCPs make a real contribution to development, economic growth and emission reductions. The CDM experience suggests pessimistic response to this regard. Accurate project-based accounting of avoided emissions on a case by case basis is almost out of reach ${ }^{23}$ since avoided emissions are calculated from a counterfactual and controversial baseline and since indirect effects of investments cannot be easily integrated into project appraisals (Shalizi et al., 2010). However, the issue at stake here, is not a problem of "project-based additionality" like in the CDM but a problem of statistical additionality that is to guarantee that the pool of projects supported by the system will yield a total of carbon abatement higher than what would have otherwise occurred.

Three cases may appear (figure 3): (i) projects pay for themselves, the carbon certificates system would thus have only helped to bridge a credibility gap inhibiting their adoption so far; (ii) projects are able to pay back their loan if a cost of carbon appears in whatever form, hopefully higher that the exed SCC; (iii) projects are in default payment because of mismanagement, technical failure, or because they actually had little chance of success. The challenge is to trigger a wave of investments in a situation of ignorance of the precise outcome of each individual project and to reach a portfolio of LCPs both economically viable and environmentally efficient. Focus on very high accuracy in the allocation of carbon certificates would end up freezing investments while laxity would lead to subsidizing projects that would have been funded anyway.

It is not the scope of this concept paper to delve more deeply into the technical principles apt to secure this statistical additionality. But the basic principles would be to (i) define a taxonomy of LCPs (size, technology, time horizon); (ii) determine the time profile of the contribution of each type of project to carbon abatement (for example railways, buildings, fossil free energy); (iii) calculate the present value of this contribution and thus the amount of carbon certificates allocated to each kind of LCP (by dividing the present value of projects by the SCC at the date of project launching).

Let $A_{\mathrm{CO} 2}$ be the estimated time profile of a project's $\mathrm{CO}_{2}$ abatement. If $t_{0}$ denotes the date of the launching of the project, $N$ the project life-time, and $i$ the discount rate, the present value of these $\mathrm{CO} 2$ abatements can be computed as follows:

$$
N P V=\sum_{t=t_{0}}^{t_{0}+N} \frac{A_{C O 2}(t) \cdot S C C(t)}{(1+i)^{t}} .
$$

Both the discount rate to be retained and the contribution of each type of project are in principle dependent on a given long run scenario ${ }^{24}$. This implies that the flow of avoided carbon attached to

\footnotetext{
${ }^{23}$ The CDM projects' approval involves heavy complexities due to the fact that accounting methodologies have to guarantee the additionality of each project to prevent issued CERs undermining existing carbon markets with "fake" emission reductions.

${ }^{24}$ Beyond the pending debate between the normative low rate (Stern, 2006) and a rate consistent with observed behaviors (Nordhaus, 2007) we remind the reader that 1 ) in integrated assessment models the discounting is in fact dominated by key parameters of economic scenarios and assumptions about damage (Weitzman (2009), Sterner (2009), Perrissin Fabert et al (2009), 2) in case of uncertainty on future growth the lower discount rates dominate the calculation (Pizer et al., 2001). There is thus a consensus that the appropriate discount rate in these matters should be far lower than the interest rates prevailing in existing capital markets.
} 
each category of project will ultimately be conventional and set by political compromise. However integrated models have accumulated sufficient information to provide orders of magnitude of the avoided carbon emissions associated, for a given growth scenario, to main types of LCPs (hydropower, solar or wind power plants, transport infrastructure, building insulation, etc). These values could be reasonably bound by systematic model comparison and sensitivity analysis, through an international expert committee and provide benchmarks for compromise values ${ }^{25}$.

Actually the most and only reliable hedge against costly arbitrariness and extreme laxity is that (i) only a share of estimated avoided carbon emissions would be allocated under the form of carbon certificates; (ii) this is a learning process in which the allocation of carbon certificates could be changed at given points in time (with no retroactivity on past allocations).

Let $\alpha$ be the share of this theoretical abatement that the Central Bank is willing to consider ${ }^{26}$. The number of carbon certificates (CC) attached to a project would thus be:

$$
C C=\alpha \cdot \frac{1}{S C C\left(t_{0}\right)} \cdot N P V
$$

In the same spirit, the monitoring of projects (and possible invalidation of the carbon certificates) has to rely on simple observable criteria to assess the degree of effectiveness of the project in comparison to its ex-ante objectives (in terms of carbon emissions when this is possible, in terms of indicators of physical achievement for transportation or building infrastructure). Building upon the experience of the CDM, it will bind public exposure of LCPs to risks and enhance audit credibility ${ }^{27}$.

\subsection{Controlling lax monetary creation, public indebtedness and the carbon bubble}

The system we have thus far sketched incorporates two mechanisms which should avoid the monetary flexibility granted by carbon assets to result in monetary inflation and systemic risks for the financial and banking system: credit is backed by carbon certificates authenticated by sound control procedures and financial products attracting private savings.

However the question deserves to be raised because default payments of a significant share of the SCCbased loans cannot be totally excluded. This would force governments to back the debt in the last resort and eventually provide "hard cash." Excess default payments might thus increase countries' debts and oblige countries' taxpayers to later pay a debt service due to misdirected and mismanaged projects.

Certainly, if the financing of LCPs does not increase potential output as much as expected, a risk of inflation acceleration has to be considered. In fact, in addition to the traditional monetary policy tools (legal reserve requirements and the interest rate for instance), a second tool could be activated with carbon certificates acting as legal reserves. This is the coefficient $\alpha$ in equation 2 , which adjusts the number of carbon certificates available for each type of project.

\footnotetext{
${ }^{25}$ In addition, this committee could build on the CDM experience to refine global assessments and adapt them to local circumstances.

${ }^{26}$ We took $\alpha=0.5$ in the numerical illustration presented in the previous sub-section.

${ }^{27}$ One could also allow NGOs and non-energy-intensive sectors (which will not receive carbon-based public support) to contest public audit reports by the official body of control on the grounds of their own investigations.
} 
One last legitimate concern is that financial intermediaries will be necessary to create assets apt to diversify the risks and to finance portfolios of projects. They may generate what Timothy Geithner calls the "non-bank financial system" 28 which facilitates the emergence of bubbles like the housing bubble and the dramatic rise of private debts that put the financial system at risk. Actually, the risk of a "carbon bubble" followed by a "carbon subprime" crisis if it turns out that LCPs do not bring the expected paybacks, is very low. Indeed while the increase of the value of real estate assets rested on very low interest rates and was unbound, the SCC value would be known with certainty. In other words the emergence of a "carbon bubble" through the assets acting as non-bank banks is blocked by the very existence of a pre-determined value of carbon.

\section{Climate Finance and Sustainable Globalization}

Let us now assume that an expanding group of countries adopt this mechanism in view of its extension at a global level as soon as there is an agreement under the UNFCCC on the value of the SCC and on the allocation and monitoring principles of carbon certificates. Still, given the orders of magnitude at stake, the generalization of carbon certificates represents a targeted liquidity injection which cannot but have systemic implications on the monetary and financial system and ultimately macroeconomic consequences. The question is whether these implications will be positive or negative.

\subsection{The status of carbon certificates in an evolving monetary and financial order}

The financial crisis in 2008 revealed the failure of the Basel process to set prudential rules apt to control the innovative capacity of the finance industry and avoid banking in a shadow. As a matter of utmost urgency the US and the EU governments have socialized "bad debts" since 2008 and the international community is in search of tools to stabilize the international financial system.

To understand how LCP-targeted monetary flexibility may be one item of the toolbox, let us remember that modern monetary and banking systems rely on the commerce of promises ${ }^{29}$ with a significant disconnection between the scale of the promises of funded economic initiatives and the existence of pre-existing counterparts. We are far removed from the time when gold and silver of the Lombards' strongbox backed the first letters of credit.

The art of managers of the modern system consists in finding the right balance between a risky laxity, releasing speculative bubbles with significant social costs when they burst, and an extreme rigor that inhibits economic activity. Such an art plays on conventional indicators such as the ratio between loans, liquid reserves, and authorized capital, or the payment into the deposit insurance system. The only "strongbox" behind this commerce of promises is essentially the working capacities of nations, which guarantees that something of value is eventually created when the money is spent. But the crashes of Iceland, Dubaï, Greece, Ireland, and the difficulties of Portugal, Spain and Italy demonstrate that the content of this strongbox is not unlimited when the creation of actual wealth falls short of the promises circulating on financial markets, including in the form of speculative bubbles.

\footnotetext{
${ }^{28}$ A non-bank bank promises "ready access to cash for those who place money in its care, even while investing most of that money in assets that cannot be liquidated at a moment's notice. But, unlike the banking system, it is not submitted to protections like prudential rules and insurance deposits." This paves the way to banking in a shadow P. Krugman, 2009.p 161)

${ }^{29}$ For a synthetic overview of the dynamics of the system, see P.N. Giraud (2001).
} 
We will not go back to the times of the Lombard bankers or of the "gold exchange standard." However debate is open as to what should be considered as a reserve asset, including the possible use of SDRs as international reserve money ${ }^{30}$. In our proposal, one theoretical advantage of carbon certificates is that they are neither backed by pre-existing wealth nor by undetermined promises, but rather by the guarantee that something of recognized value will eventually be created (insulated houses, renewable energies, rail or waterways).

The idea of creating a new international reserve asset based on $\mathrm{CO}_{2}$ emission reduction may look odd. It is however no more far-fetched than the old convention that makes gold one of the very first reserve assets accepted worldwide. Given the magnitude of both environmental concerns and the financial crisis it is perhaps timely to open up innovative avenues to address the global climate externality. Symptomatically, IMF experts, Brendenkamp and Patillo (2010) drew a link between the reform of the international monetary system and the climate affair. They suggested 1) using available excess SDR reserves from developed countries to fill up a green fund dedicated to leverage capital for LCPs, 2) to consider the SDRs converted into equities of the fund as countries' reserve assets ${ }^{31}$.

This is not the type of link with the IMF which could be derived from the system sketched in our paper. The origin of the carbon-based international reserve asset would be the carbon certificates held by Central Banks of member countries and which could accrue to their IMF account. The stock of carbon-based reserve assets would thus gradually be increased by the subscription charge in carbon certificates paid by Central Banks. The consolidation at the IMF level of the security tools presented in section 2 would help strengthen the control of the total amount of carbon-based credits in circulation. This would be done by a change in the ratio $\alpha$ of carbon certificates per unit of investment.

A double check would thus be implemented on the system: a financial check by the IMF coupled to a physical verification of the projects' effectiveness by expert bodies near the UNFCCC would indeed guarantee that real value has been created (rails or solar plants do not vanish).

\subsection{Clearing up a foggy business environment and backing a "green" recovery}

It can legitimately be argued that, given the opportunity cost of LCPs relative to the projects that would be implemented in absence of GHG constraints, introducing a bias in their favor could crowd out other investments and eventually result in a slowdown of overall activity. But there is little chance of making such crowding out happen. First, the suggested mechanism would primarily redirect investment within the infrastructure sectors and the incremental capital cost would be only $3 \%$. Second, the risk of crowding out other productive investments is all the smaller as one major source of disequilibrium for the world economy is the paradox of the coexistence of a vast pool of savings and a lack of productive investment opportunities to attract borrowers (Zenghelis (2011).

\footnotetext{
${ }^{30}$ Symptomatically, this was suggested by Governor Zhou of the People's Bank of China in a web-based article just before the April 2009 G20 meeting. Governor Zhou recalls the vulnerabilities and systemic risks in the existing international monetary system, calls for worldwide reflection on an international reserve currency anchored to a stable benchmark, and argues in favor of reformed SDRs.

${ }^{31}$ This would be a neutral swap without upfront budgetary costs if the dividends offered to shareholders were equivalent to the interests of their reserves expressed in SDRs. The green fund is used as a counterpart to low cost bonds sold to private or public investors and therefore can leverage a multiple of its paid-in capital. Still, one criticism is that the fund dips into the stock of available SDRs and crowds out reserves which, far from being in excess, may be necessary in the case of a major world monetary crisis.
} 
One might even argue that a carbon-based financial architecture could contribute to overcoming this paradox by changing the preference of investors over the last decade for very liquid or speculative options (US treasury bonds or real estate and commodities) at the expense of genuine investments in future potential growth ${ }^{32}$. The new financial economy confronts indeed potential long-term investors with a kind of "Buridan's donkey dilemma",33, the donkey which hesitated too long between eating oats or drinking water and died of hunger and thirst. A carbon-based financial architecture, instead of crowding out productive investment, could help the "donkey" to decide, and divert part or the savings from speculative options. For example institutional investors like pension funds currently tend to be cautious enough to avoid getting engaged with products that look safe while masking ventured assets.

This diversion from speculative options is all the timelier as the context of reduction of public and private spending to reimburse outstanding debts may generate a failure on the demand side of the economy. Within this framework, when the IMF or the European Central Bank intervene to rescue a bankrupt country, part of the financial support could be delivered under the form of carbon assets, so that it would be conditional on the launching of a wave of low carbon investments. The difference with the traditional Keynesian compact is that credits facilities are backed on infrastructures as real assets.

Another side benefit of the issuance of carbon-based international reserve assets would be to lower the tensions on exchange-rates. These risks are partly due to the high precautionary reserves accumulated in the emerging world after the 1980s/1990s financial crises in Latin America and Asia. This "warchest" of official reserves is a self-insurance to protect export-led growth strategies against exchangerate appreciation. Carbon-based reserve assets could then allow emerging economies to increase and diversify their foreign exchange reserves. They would thus be less inclined to run Balance of Payment surpluses, since they would get their reserves in proportion to emissions reductions they finance domestically. This would also contribute to spreading the gains from seigniorage and reducing the perverse effect that forces the US to pump out more US\$ assets for global reserves.

More fundamentally, carbon-based reserve assets would help solve structural imbalances of the world economy: huge capital flows from China to the US, the catching up of emerging economies grounded on export-led strategies sometimes at the cost of backwardness of the domestic infrastructure, undermine the social contract in many OECD countries. $60 \%$ or more of carbon savings investment (WDR, 2009) would benefit developing countries. Since the new carbon-based financial products could be attractive as well for private savings of emerging countries, the carbon-based finance would result in domestically reorienting a fraction of the savings that currently flow into the rich countries' banking systems. The strategic choice for these economies would thus be between a) continuing mercantilist exchange rate policies and purchasing power gains in favor of reserves accumulation and b) implementing a more "endogenous", inward oriented, growth pattern. This second option might become attractive with a higher guarantee that less export-oriented strategies do not lower the pace of growth and then trigger domestic social tensions.

\footnotetext{
${ }^{32}$ Ben Bernanke, Governor of the U.S. Federal Reserve Board recognized as far back as 2005:"During the past few years, the key asset-price effects of the global saving glut appear to have occurred in the market for residential investment, as low mortgage rates have supported record levels of home construction and strong gains in housing prices."

${ }^{33}$ The legend of Buridan's donkey comes from a caricature of Jean Buridan (1292 - 1363), professor at the University of Paris, who theorized the postponement of decisions in the hope of better information in the future. This legend is a caricature of his philosophy.
} 
A climate-friendly financial architecture would then help pinpoint the thin pathway between extreme rigor which would freeze economic growth (and throw some regions into recession) and extreme laxity which would push the burden of debt onto future generations. It would transform the climate challenge from a pure constraint to a lever for sustainable growth backed by a 'green' content. This would have a critical impact on the developing and emerging economies which will account for a dominant share of the infrastructure market over coming decades.

Annex 1 countries would assume their historical responsibility in the climate affair and the financial breakdown, without putting huge pressure on their weakened taxpayers. They would do so in a way consistent with their budgetary constraints and their concerns about employment and social stability. Embarked upon in the form of a forward contract, with carbon reduction as an effective underlayer, governments, industries and trade-unions would then be interested in the emergence of any form of carbon price.

\section{Conclusion}

This paper starts by explaining how climate finance can get climate negotiations out of the difficulties of reaching a global deal on binding emission targets or any global carbon price signal in the near future. It ends by presenting a framework which, in addition to carbon abatement, would generate a wave of "green growth" recovery (Aglietta, 2011, UNEP, 2010) through large scale infrastructure investments in both developed and developing countries.

This framework requires a more in depth general equilibrium analysis to weigh its potential costs and risks against its potential benefits. We argue however that, in the absence of global carbon markets, a massive redirection of world savings toward LCPs could be made, at least public budgetary cost, if (i) specific credit facilities, based on carbon certificates recognized as new reserve assets or new equity, were offered to LCP developers, (ii) the value of these carbon certificates, at the time of the loan, were the SCC determined by an agreement amongst the Parties to the UNFCCC. We firmly believe that such agreement upon a SCC will make it possible to enhance the efficiency of climate finance by launching a carbon price surrogate and preventing the fragmentation of climate finance without resorting to a binding mechanism. It will encourage both unilateral initiatives and the implementation of the Green Climate Fund adopted at the Cancun Conference as part of the carbon certificates can bring additional resources to this fund. Ultimately, when enough partners are involved in this mechanism, it might be interesting to allow the IMF to consider carbon certificates as international reserve assets.

In our opinion, if such an architecture were implemented, it would first foster economic recovery without creating new excess rights to future wealth as carbon certificates have tangible counterparts such as avoided carbon emissions and newly installed infrastructures. Second, domestically reorienting a fraction of private savings from emerging economies, it would contribute to calming current tensions about currencies and allow emerging countries to increase and diversify their foreign exchange reserves. Third, it would change the political economy of climate negotiations since expanding the system would be in the interest of all countries. Annex 1 countries would be incited to accelerate the launching of carbon prices that would reduce the default payment risks of LCPs and non-Annex 1 countries would benefit from credible financial support for climate policies aligned with their development priorities. 


\section{References}

AGF. 2010. "Report of the Secretary-General's High-level Advisory Group on Climate Change Financing". The United Nations, New York.

http://www.un.org/wcm/content/site/climatechange/pages/financeadvisorygroup/pid/13300

Aglietta, M., 2011. Financer la croissance soutenable. In La finance durable. Une nouvelle finance pour le XXIe siècle. RB Edition.

Aldy, J. E., Barett, S., Stavins, R. N., 2003, "Thirteen plus one: a comparison of global climate policy architectures". Climate Policy, Vol 3, Number 4, 2003 , pp. 373-397(25)

Aldy, J.E. and Stavins, R.N, 2007. Architectures for agreement: addressing global climate change in the post-Kyoto world. Cambridge University Press.

Bali Action Plan. 2007

H. Bredenkamp and C. Pattillo, 2010. Financing the Response to Climate Change. IMF Staff Position Note.

C. De Gouvello, I. Zelenko, 2010. Scaling up the Financing of Emissions Reduction Projects for Low Carbon Development in Developing Countries Proposal for a Low-carbon Development Facility (LCDF). Policy Research Working Paper. World Bank.

Edenhofer, O., C. Carraro, J.-C. Hourcade, K. Neuhoff, G. Luderer, C. Flachsland, M. Jakob, A. Popp, fJ. Steckel, J. Strohschein, N. Bauer, S. Brunner, M. Leimbach, H. Lotze-Campen, V. Bosetti, E. de Cian, M. Tavoni, O. Sassi, H. Waisman, R. Crassous-Doerfler, S. Monjon, S. Dröge, H. van Essen, P. del Río, A. Türk (2009). "RECIPE - The Economics of Decarbonization." Synthesis Report, Nov 2009.

Energy Modeling Forum, 2010. "International, U.S. and E.U. Climate Change Control Scenarios: Results from EMF 22”. Energy Economics. Vol. 31, Supplement 2 pp. 63-306.

Foley, D., 2009. "Economic Fundamentals of Global Warming". Edward Elgar Publishing, p. 332. http://homepage.newschool.edu/ foleyd/FoleygwextRev1a.pdf

P-N. Giraud 2001. Le commerce des promesses. Petit traité sur la finance moderne (re-edition 2009). Le Seuil.

Grantham Research Institute, 2009. Meeting the Climate Challenge: Using Public Funds to Leverage Private Investment in Developing Countries.

http://www2.1se.ac.uk/GranthamInstitute/publications/Other/Leveragedfunds/Meeting\%20the \%20Climate\%20Challenge.aspx

R. Guesnerie, 2010. «Pour une politique climatique globale». Blocages et ouvertures. CEPREMAP. Editions de la rue d'Ulm.

Hourcade, J.-C. et F. Ghersi (2002), «The Economics of a Lost Deal : Kyoto - The Hague Marrakesh », The Energy Journal 23 (3) : pp. 1-26 
J-C. Hourcade, Shukla, P.R. and Mathy, S., 2008, "Untying the Climate-Development Gordian Knot - Economic Options", in R. Guesnerie, H. Tulkens, (eds.), Politically Constrained World, MIT Press, 2006, 19 p. http://www.centre-cired.fr/spip.php?article407

International Energy Agency IEA, 2009. World Energy Outlook 2009. Paris, OECD/IEA edition.

IPCC. Climate change 2007: Mitigation. Contribution of working group III to the fourth assessment report of the intergovernmental panel on climate change. Cambridge University Press, Cambridge, UK and New York, NY., 26.

A. Kossoy, P. Ambrosi, 2010. State and Trends of the Carbon Market 2010. World Bank Report.

P. Krugman, 2008. The return of depression economics and the crisis of 2008. Ed. W. W. Norton \& Company, 2009. 224p.

R. G. Lipsey, K. Lancaster, 1956. The General Theory of Second Best. The Review of Economic Studies, Vol. 24, No. 1, pp. 11-32.

Maclean, J., J. Tan, D. Tirpak, V. Sonntag-O’Brien, and E. Usher. 2008. "Public Finance Mechanisms to mobilize Investment in Climate Change Mitigation". United Nations Environment Programme Sustainable Energy Finance Initiative.

Neuhoff, K., S. Fankhauser, E. Guerin, J.-C. Hourcade, H. Jackson, R. Rajan, and J. Ward, 2009. Structuring international financial support for climate change mitigation in developing countries. Working Paper.

Paris Declaration on Aid Effectiveness. February 2005

B. Perrissin Fabert, P. Dumas, J-C. Hourcade, 2009. "What Social Cost of Carbon ? A mapping of the climate debate", Working Paper CIRED.

Shalizi, Z., and F. Lecocq, 2009. "Climate change and the economics of targeted mitigation in sectors with long-lived capital stock”. Policy Research Working Paper No. 5063, The World Bank.

Shukla, P. and S. Dhar, 2011. Climate agreements and India: aligning options and opportunities on a new track. International Environmental Agreements: Politics, Law and Economics, Springer, pp1-15.

N. Stern, 2010. Presidential Address Imperfections in the Economics of Public Policy, Imperfections in Markets, and Climate Change. Journal of the European Economic Association. MIT Press.

UNEP. 2010. Green Economy: Driving Green Economy through Public Finance and Fiscal Policy Reform. United Nations Environment Programme.

UNEP, 2010. Bilateral Fianance Institutions and Climate Change. A mapping of 2009 Climate Financial Flows to Developing Countries. United Nations Environment Programme.

UNEP, 2009. Annual Report. Seizing the Green Opportunity. United Nations Environment Programme. 
UNFCCC. 2007. Investment and Financial Flows to Address Climate Change. Bonn: UNFCCC. see http://unfccc.int/files/cooperation_and_support/financial_mechanism/application/pdf/background_pap er.pdf

Ward, J., S. Frankhauser, C. Hepburn, H. Jackson, and R. Rajan, 2009. Catalysing low-carbon growth in developing economies. Public Finance Mechanisms to scale up private sector investment in climate solutions. United Nations Environment Programme.

World Bank. 2009. World Development Report 2010: Development and Climate Change. Washington DC: The World Bank.

Zenghelis, D., 2011. A Macroeconomic Plan for Green Recovery. Policy Paper. Centre for Climate Change Economics and Policy. Grantham Research Institute on Climate Change and the Environment. 


\section{Appendix 1: An illustration of the accounting circuit of carbon-based assets}

This appendix is not an operational proposal. It highlights the basic principles of one possible monetary circuit that make it possible to turn $\mathrm{CO}_{2}$ abatement into legal monetary reserves of banks. We hope that specialists in project finance will pursue, following this intuition, the quest for manageable accounting and financial devices apt to scale up climate finance.

Let's consider a low-carbon project $A_{\mathrm{LCP}}$ and a business as usual project $\mathrm{B}_{\mathrm{BAU}}$ both requiring a $\$ 1000$ loan in order to cover identical upfront costs. These projects differ in a) their expected $\mathrm{CO}_{2}$ emissions $\left(\mathrm{A}_{\mathrm{LCP}}\right.$ emits $12 \mathrm{tCO}_{2}$ less than $\mathrm{B}_{\mathrm{BAU}}$ b) the interest rate required by a bank $\mathrm{C}$ for a 5 -year loan maturity (respectively $20 \%$ and $10 \%$ ). As a consequence, the total risk-adjusted cost of $A_{L C P}$ is $\$ 1600$ instead of $\$ 1300$ for $\mathrm{B}_{\mathrm{BAU}}$.

Let's assume now that a government is willing to enhance the credit rating of LCPs. It decides to issue a given amount of carbon certificates (CC) and deliver them to investments and development banks in a proportion $\alpha$ of expected $\mathrm{CO}_{2}$ abatement by LCPs funded by the banks. CC can be considered as a public guarantee on LCP loans aimed at reducing the interest rates required by the banks for this type of project. At this stage this public device implies no disbursement of hard cash as CC basically consist of fiat money (with a face value defined by the SCC) that pays for "unpriced" services of $\mathrm{CO}_{2}$ abatement provided by LCPs.

One key element to prompt the banks to add carbon finance on the short list of their priorities is to gradually allow the transfer of CC into banks' legal reserves after due verification that projects meet their $\mathrm{CO}_{2}$ abatement expectations ${ }^{34}$ and have produced the expected actual wealth. Hence, successful projects will expand further lending capacity of the bank. Figure 1 describes the articulation between monitoring mechanisms and the transformation of $\mathrm{CC}$ into legal reserves.

The critical point is what happens if part of the expected $\mathrm{CO}_{2}$ abatement is not delivered. A double accounting of debt payments from $\mathrm{A}_{\mathrm{LCP}}$ is necessary to secure both the economic and the environmental integrity of the mechanism. The mechanism goes as follows:

- With $\alpha=0.5$, bank $\mathrm{C}$ receives $6 \mathrm{CC}$ that are directly lent to $\mathrm{A}_{\mathrm{LCP}}$ together with $\$ 1000$ at a reduced interest rate of, say, $10 \%$. CC are listed in the asset column of bank $\mathrm{C}$ as a loan (for a given face value of say $\$ 50$ per CC) to $A_{L C P}$ and appear in the liability column of $A_{L C P}$ as a carbon debt. . The liability column of $A_{L C P}$ is thus composed of a financial debt and a carbon debt. Both loans make $\mathrm{A}_{\mathrm{LCP}}$ deposits listed in the liability column of bank $\mathrm{C}$.

- At the beginning of the operation phase of $A_{L C P}$ (see $T_{1}$ in Fig.1) an independent authority certifies that the equipment built complies with the agreed plan $^{35}$ and allows the project proponent to reimburse say $50 \%$ of its carbon debt in one shot. Bank $\mathrm{C}$ can then turn the corresponding amount of $\mathrm{CC}$ into legal reserves. The Central Bank recognizes these new legal reserves and makes $\mathrm{CC}$ become hard cash. Bank $\mathrm{C}$ can either deposit these reserves in its central bank account or use them to provide new loans. During the operation phase

\footnotetext{
${ }^{34}$ In this illustration we do not present the case where CC are turned into banks' capital under the form of carbon equity.

${ }^{35}$ The auditing process does not consist of an accurate project-based verification of $\mathrm{CO} 2$ abatement over the whole operation phase of the project. Instead, it aims at verifying whether the construction phase has been carried out appropriately and meets the requirements defined in the taxonomy of LCPs that allows the project to claim a conventional amount of CC.
} 
(see $\mathrm{T}_{2}$ in Fig.1) $\mathrm{A}_{\mathrm{LCP}}$ reimburses its financial debt with its revenues in $\$$ and its carbon debt by abating $\mathrm{CO}_{2}$. At the end of the payback period (see $\mathrm{T}_{3}$ in Fig.1) an ultimate verification is carried out by the same authority. If $\mathrm{A}_{\mathrm{LCP}}$ has generated in due time the expected abatement, then it is allowed to reimburse all its remaining carbon debt.

- If the project fails to meet its abatement objective, the project proponent has to pay back uppermost the face value of the remaining carbon debt to a Green Fund. Corresponding $\mathrm{CC}$ are cancelled and the Bank cannot increase its legal reserves. This incites the Bank to select projects with real environmental efficiency. Indeed, on top of not increasing its legal reserves, funding dubious projects increases the default risk of these projects and therefore potential loss for the banks as the carbon debt has to be reimbursed before the financial one.

Figure 1: The accounting circuit of carbon-based assets

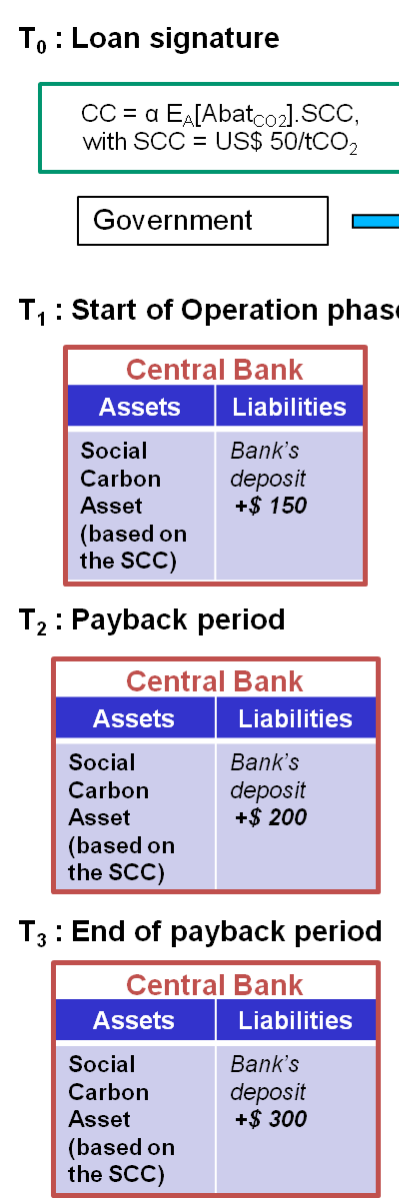

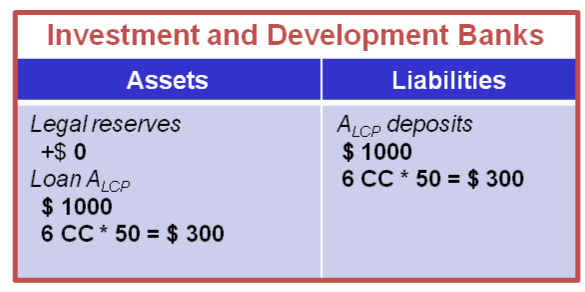
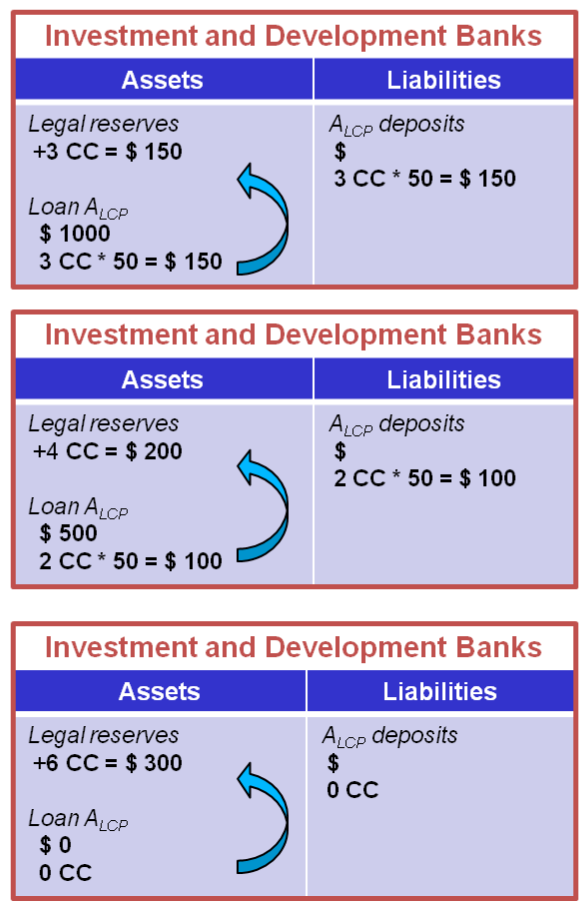
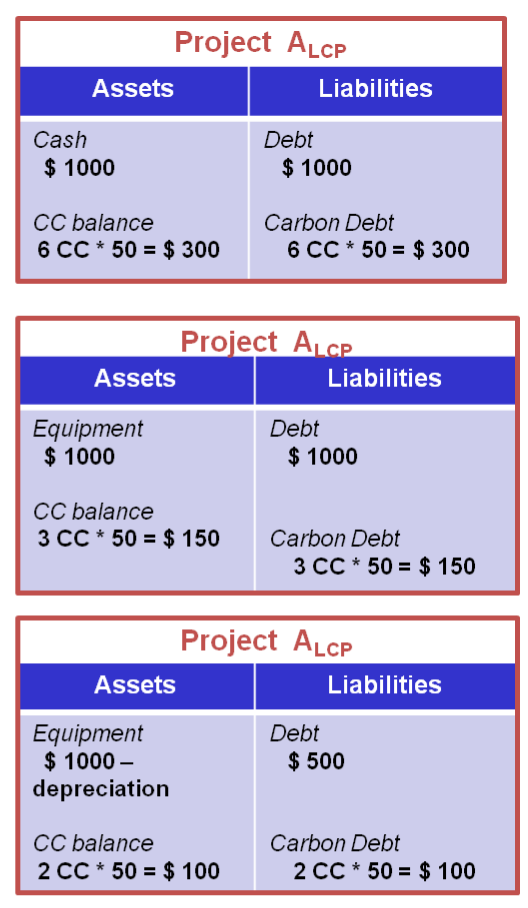

\begin{tabular}{|c|c|}
\hline \multicolumn{2}{|c|}{ Project $A_{\text {LCP }}$} \\
\hline \multicolumn{1}{|c|}{ Assets } & Liabilities \\
\hline Equipment & Debt \\
$\$ 1000-$ & $\$ 0$ \\
depreciation & \\
CC balance & Carbon Debt \\
0 & 0 \\
\hline
\end{tabular}


Jean-Charles Hourcade, Baptiste Perrissin-Fabert and Julie Rozenberg

CIRED Working Papers Series 